\title{
II. CONSTITUTIONAL AND ADMINISTRATIVE LAW
}

Information for citation:

Aristov E. V. Nauchnye interpretatsii soderzhaniya ponyatiy "sotsial'noe gosudarstvo» $i$ «sotsial'nost' gosudarstva» i ikh priznakov ["Welfare State" and "Sociality of the State": Scientific Interpretations of the Concepts and their Features]. Vestnik Permskogo Universiteta. Juridicheskie Nauki - Perm University Herald. Juridical Sciences. 2017. Issue 38. Pp. 417-429. (In Russ.). DOI: 10.17072/1995-4190-2017-38-417-429.

UDC 342.7

DOI: $10.17072 / 1995-4190-2017-38-417-429$

\section{“WELFARE STATE” AND "SOCIALITY OF THE STATE": SCIENTIFIC INTERPRETATIONS OF THE CONCEPTS AND THEIR FEATURES}

\section{E. V. Aristov}

Perm State University

15, Bukireva st., Perm, 614990, Russia

ORCID: 0000-0003-2445-3840

ResearcherID: D-2713-2016

Articles in DB "Scopus" / "Web of Science":

DOI: $10.17072 / 1995-4190-2015-3-8-14$

DOI: $10.17072 / 1995-4190-2016-32-149-157$

e-mail:welfarestate1@gmail.com

Introduction: the article is devoted to the scientific discussion about the scope and content of the "welfare state" and "sociality of the state" concepts as parts of the state legitimacy constitutional principle. Purpose: to study different doctrinal approaches in Russian legal science to defining the concepts "welfare state" and "sociality of the state". Methods: the methodological framework of the research is based on the general dialectical method of cognition and a set of general scientific methods: systemacity, analysis and synthesis, concretization; the comparative law research method is used as the main specific scientific method. Results: the paper reveals lack of scientific interpretation of the "welfare state" and "sociality of the state" concepts. It identifies different approaches to these concepts in terms of different branches of jurisprudence. The author reviews and describes different interpretations of the concepts in chronological order how they appeared in thesis research works. Conclusions: as the analysis has shown, the concept "sociality of the state" is seldom used in scientific works, let alone its interpretations. Moreover, this concept lacks any official interpretation in the Constitution of the Russian Federation.

Keywords: sociality of the state; welfare state; social function of the state; relevance; constitutional principle; classification; definition

\section{Information in Russian}

\section{НАУЧНЫЕ ИНТЕРПРЕТАЦИИ СОДЕРЖАНИЯ ПОНЯТИЙ «СОЦИАЛЬНОЕ ГОСУДАРСТВО» И «СОЦИАЛЬНОСТЬ ГОСУДАРСТВА» И ИХ ПРИЗНАКОВ}

\section{Е. В. Аристов}

Кандидат юридических наук, доцент кафедры предпринимательского права, гражданского и арбитражного процесса Пермский государственный национальный исследовательский университет 614990, Россия, г. Пермь, ул. Букирева, 15

(C) Aristov E. V., 2017 
ORCID: 0000-0003-2445-3840

ResearcherID: D-2713-2016

Статьи автора в БД «Scopus» / «Web of Science»:

DOI: $10.17072 / 1995-4190-2015-3-8-14$

DOI: $10.17072 / 1995-4190-2016-32-149-157$

e-mail: welfarestate1@gmail.com

Введение: статья посвящена рассмотрению содержания научной дискуссии об объеме понятий «социальное государство» и «социальность государства» как части содержания конституц̧ионно-правового принцуипа легитимности государства. Цель: исследовать различные доктринальные подходы, существующие в российской юридической науке, к определению понятий «соичальное государство» и «сочиальность государства». Методы: методологическую базу исследования положень всеобщий диалектический метод познания, а также совокупность общенаучных методов: системность, анализ и синтез, конкретизация. Основным частноправовым методом исследования стал сравнительно-правовой анализ. Результаты: выявлено отсутствие научной интерпретации понятий «социальное государство» и «социальность государства». Установлены различные подходы к данным понятиям с точки зрения научных специальностей юридических наук. Дана характеристика различных интерпретаций понятий «сочиальное государство» и «социальность государства» в хронологии их формулирования в диссертациионых исследованиях. Выводы: к числу важнейших общественных благ следует отнести благополучие общества. Государство благосостояния само по себе является благом; благополучие как публичное благо предполагает признание неравенства возможностей в рамках рыночной экономики и необходимость государства проявлять инициативу в направлении обеспечения решения проблемы такого неравенства. При этом само государство может производить блага, не отвечающие признакам публичности. В то же время публичные блага могут создаваться частным сектором экономики.

Ключевые слова: социальность государства; социальное государство; социальная функция государства; релевантность; конституционный принцип; классификация; дефиниция

\section{Introduction}

The research on the phenomena of the welfare state and sociality of the state requires global coverage, evaluation of the extent of research already conducted in this area, and development of a theoretic framework comprising the relevant scientific concepts, constructions, mini-theories, classifications and definitions proposed by other authors.

Only this, performed in accordance with high scientific standards, proper diligence, necessary criticism and respect for the thoughts of other authors, makes it possible to objectively define an author's own area of unique relevant scientific assumptions and conclusions. On the other hand, only the scrupulous consideration and description of all the "mosaic elements", i. e. relevant and unique authors' input made into increasing the knowledge about the welfare state and the sociality of the state, can piece together the mosaic picture of the scientific image (developed through consolidated efforts) of the subject-object area in question.

\section{Dissertations on Juridical Sciences}

In accordance with the concept of Z. H. Makedonskaya, the "welfare state deals with management and control of all the social processes: those associated with providing the rise in the population's living standards, those aimed at the improvement of the society's social structure which is the purposeful activity of the state on developing all the social sphere of the society. The nature of the welfare state is in its duty to render social services to the population and this is not equal to replacement of the economic freedom, commercial and entrepreneurial activity of the society members with the state's control. The main task is creating the favorable legal and organizational environment for the citizens, so that they could reach material wealth for themselves and their families through their own efforts." This author considers the supremacy of law to be an essential characteristic of the rule-of-law state (this means that the state and its institutions are linked with law), and according to her concept "the supremacy of the right-protecting and social content of each law takes on a social meaning for 
a welfare state" [16]. The author identifies several groups of constitutional fundamentals of the state social essence, noting that each group rests on "social relations associated with creating the conditions providing for a good life and free development of an individual, regulated by the Russian Federation Constitution, and being non-uniform in their character".

As per the scientific views of E. M. Andreeva [2], the basement of the state's sociality is the notion of the individual's good life and the corresponding right of his, and the notion of the social function of the state (the author honestly and reasonably notes that "the scientific category of the social function of the state was distinguished in the works of a number of scientists in the $80 \mathrm{~s}$ ", but makes her own contribution to the development of its contents perception). The author emphasizes that "the social sphere of the society kind of accumulates all the grounds for the society reproduction and development; it is closely connected with other spheres, it does not have space or time limits and is of complicated systemic character". The next concept of E. M. Andreeva is also of interest: "The minimum social guarantees are established in the process of the social standardization which is a legal regulation of the most meaningful norms at the level of the minimum social standards. Contrary to the traditional technical standardization associated with regulating the process of producing material values and rendering services, the social standardization regulates the processes of their distribution and consumption. The concept of the "minimum social standards" is close in its meaning to the "minimum social guarantees" and "minimum living standards criteria" concepts that are widely used in scientific publications. The institution of the state social guarantees, as the regulator of the scope of the social responsibilities of the state to an individual, is a specific state legal institution for the model of the welfare state that is now being developed in Russia".

S. E. Korobov [13] viewed the welfare state as "the result of the confrontation and synthesis of the state that rests on the liberal democratic values and the socialist state that announced the right of the citizen for a good living standard to be its main field of activity". He describes the sociality of the state through the notion of the state social function, understanding it as one of the principal fields (lines) of the state activities in the social sphere of the public relations on providing a proper living standard, settling the social conflicts and exercising the approved interests of the citizens, on the basis of the social standards acknowledged by the society and fixed by law.

The theoretical opinion of A. V. Gurlev [9], considering "the human right to life to be the core value of the welfare state", emphasizes the historicity of the welfare state development and model building. The author writes that "the establishment of the legal framework of the social relations is a historical process, and the content of the legal norms that regulate the social relations depends both on the traditions of this society and the specific economic, political and ideological factors". The author highlights the principle of freedom, equity and justice as the key principles of the welfare state.

D. G. Cherepennikov sees the functioning and the development of the welfare state "at the background of preserving the amalgamation (heterogeneity) of the society and the authorities" in the conditions of contradictions and uncertainties; correspondingly, the "the society's and the authorities' disintegration, fragmentarity and amalgamation" are viewed as the factors that make it difficult to develop and realize the proper and effective social policy in Russia [30].

In her Candidate of Sciences Dissertation, O. V. Rodionova [22] reasonably and fairly contrasts the welfare state and the liberal "cheap state" not overburdened with social care; and defines the welfare state through the right to good life by understanding it as "the welfare state category". In the opinion of the author, "the rule-oflaw state and the welfare state are not antagonistic, and a welfare state can be the next phase of the rule-of-law state development at a higher level of the social advancement". O. V. Rodionova [23], later in her Doctoral Degree Dissertation writes about the emerging "contour of new neopaternalistic state that performs its social function on the basis of quite different principles" and presents the modern welfare state as "the target pursued by the society with the state-like arrangement", and "the phase of the welfare state development that follows the phase of the paternalistic welfare state". As the author puts it, "a social function is the activity of the state aimed at minimizing the differences in the access to the benefits 
for the members of the state, for the purpose of providing stability (self-preservation) of the society. It is a definite, historically concrete system of actions, ways and means of their implementation. The actions integrate different social groups into a unified society with the state-like arrangement". At present, the social function of the state is at the point when its optimum status is being defined by the state in accordance with the current conditions of the natural and social environment. The vector of "state social function" system development changes to the extent that its managing parameters change. The crucial point of the state social function development is defined by the transformations that happened in the society during the last decades. In particular, the globalization processes typical for the modern epoch (information, economic, demographical ones and others) determined the change in the "state social function" system development vector. O. V. Rodionova, together with a number of other authors, puts the notion of the individual's good life and his corresponding right as the basement of the state's social character.

As A. A. Adukhov sees it, the social character of the state is its inherent part as an element of its form. The author proves that there is a close and indissoluble link between the form of the state and its social purpose (essence). With this, "the social purpose of the state as a complex of functions realized by the state, is a public authority manifestation of its social essence in specific historical conditions. The form of the state is the organization of public authority in the society, within which the state achieves its social purpose. Each of the state's form elements (form of government, form of the state territorial structure and political regime) is conditioned by the social essence of the state, being its specific manifestation. The elements of the state's form are in complex dynamic interrelation based on the historical dynamics of the state's social purpose which as not unchangeable and rests on a complicated complex of different socialeconomic, political and cultural factors. The historical dynamics of the state's social purpose is the factor that provides for the unequal correlation of the elements making up the content of the state's form. At different phases of the state's historical development, the correlation of the elements of the state's form is not the same within the framework of this system. With this, the political regime serves as the most flexible element that finally predetermines the possible evolution of all the other elements, their role and meaning inside this system. A complex of the social functions is the most vivid manifestation of the modern state's social purpose" [1].

N. A. Elbaeva, who considers the notion of the individual's good life and his corresponding right to be the basement of the state's sociality, proposes the following concept structures: "The welfare state is a rule-of-law democratic state, that announces social justice as the core value; the policy of the state is aimed at providing the citizens with good life and social protection, at minimizing the social risks and creating conditions for realizing the artistic (work) potential of the individual. The welfare state is an independent type of the rule-of-law state where the optimal relations are established between the individual, the social communities and the state; and the necessary conditions and opportunities are created for the utmost realization of the inherent rights and freedoms of a human including the universal right for a good life" [11].

According to the concept of U. A. Starshova, "the welfare state needs to be viewed in three aspects: in the conceptual aspect - as an idea, in the normative aspect - as one of the fundamentals of the constitutional order fixed in Chapter 1 of the RF Constitution, in the practical aspect - as the activities of the state institutions on solving the social issues". As this author interprets it, the notion of the "welfare state" is the "essential characteristic of the state" reflecting the "humanistic character of such a state with the activities meant for and aimed at providing free development of individuals and creating good living conditions for them". The author describes the key term of the "good life" as a multi-aspect notion that includes "a sufficient level of the material resources for a person's existence, and in particular - the material security at the advanced society standard; conditions for keeping the person healthy and for good rest", sufficient opportunity for a person to get food, clothes and housing. With this, as the author sees it, "the legal form of the welfare state" is the "mechanism of the social policy": this mechanism "should rest on the following basic fundamentals: introduction of the minimum social standard; 
targeting of providing the minimum subsistence level and insurance; regulation of the labor relations and income; decentralization, regionalization and deconcentration; reaching agreements; legislative regulation of the labor market" [26].

L. A. Rezvanova interprets the welfare state as "the public authority arrangement of the society that functions on the principles of equity, social justice and social solidarity, the purpose of which is providing a good life and free development for each person, through the fixation and the realization of the objectively established social rights, duties and prohibitions" [21].

In the concept of A. V. Sigarev, the purposes of the welfare state (that in the author's opinion include providing a good life and a free development for a person) should be viewed as the natural ones (but not the ones having a conjuncture ideological character), correspondingly, the establishment of the welfare state should be viewed as the "result of the democratic legal statehood evolution". This author (differentiating between the welfare state and the "paternalistic type state") describes the essence of the welfare state through "the legal fixation and the realization of the policy on supporting and growth of the people's prosperity in the activities of the authorities". The content of the welfare state activities is described by the author through the concepts of the society's interests and the development of the "human potential" of the nation. According to A. V. Sigarev's opinion, "the welfare state, the social and economic policy of the state, the social market economy are all the logically connected constitutional legal categories having their own content and expressed (or need to be expressed) in the corresponding norms of law". Let us also note that this author makes an interesting conclusion that "the current RF Constitution fails to clearly reflect the systematic character of the welfare state" [25].

The scientific beliefs of G. V. Tkacheva focus on the tendency of the "further socialization of the Russian state". The author formulates the concept of "the objective necessity for forming the dominating role of the social function in the system of the principal areas of activity of the modern Russian state" [27].

The concept of N. A. Baieva is built around the interpretation of the welfare state as the "political legal organization resting on the principles of formal equity, freedom and social justice, on the social rights and freedoms of an individual and of a citizen, which are legislatively fixed, secured and guaranteed, mostly by the legal guarantees". The concept is supplemented with the theoretical construct about the importance of the juridical justice principle (as the "criterion of the welfare state activities character, resulting from the social existence essence"), which structure is described through 3 elements (the volume of requital, the volume of demand and the legitimacy of the estimation") with the content coming out from the "welfare state purpose". With this, as the author sees it, the juridical guarantees of the welfare state "are meant not only for the creation of the welfare state establishment, development and functioning, not only for being the means of supporting these processes, but for solving the tasks aimed at its improvement" [4].

A. E. Evstratov uses the "social harmony" as one of the key notions, and interprets the welfare state as "the model of building the system of government that provides for the balance (harmony) between personal and public interests that exist in different forms, in different social and economic conditions and during different historical epochs. This model is expressed in two connected elements: internal (legal awareness of the citizens) and external (political forms)". In A. E. Evstratov's opinion, "the sociality of the state is a special ideal that rests on a forever harmony (but not struggle) of two actually opposed but naturally united features of a person - a private, a selfish one that strives for the separation and dominating over the others (expressed in the society) and a public, a comprehensive one striving for preserving the whole (expressed in the state). These two phenomena are similar in force but are manifested differently. This is an ideal that presents the condition of mutual balance between the interests of the state and the community, between the public interest and the private interest". According to the extremely maximalist opinion of the author, the Russian Federation is not a welfare state [10].

In T. V. Yakhontova's scientific views, the welfare state is interpreted as an "independent type of the rule-of-law state that provides for establishing the optimal relations between the society, the individual and the state, while preserving the principle 
of the formal legal justice; conducts a coherent policy aimed at the creation of the material and spiritual conditions of good life for its citizens, at minimizing social risks and smoothing the social inequality; strives for the establishment of justice to reach the society's welfare and stable nationnal political-legal and economic development". T. V. Yakhontova decomposes the "welfare legal state" defined by her, into the following complex of the research horizons: 1) "organizational functional level" where the genesis is researched as well as major types of activities of the welfare legal state institutions"; 2) "institutional normative level that fixes the establishment of the welfare state institutions at the level of their legislative provision, first of all - of the constitutional legal one; 3 ) "social and economic level which defines a specific economic public order with its main criteria of the "public welfare" (public interest) that settles the state policy in the sphere of the property as the state social institution"; 4) "legal cultural aspect that defines the contribution of different institutions of the welfare legal state to a normal life activity of the Russians". One more important conclusion of this author is that "the communitarian synodic values, being the traditionally dominating values for the majority of the population of Russia, stipulate to a large extent the real tendencies, create the basement for overcoming the policy of the liberal legal egalitarianism and creating the domestic institutions of the welfare rule-of-law state" [31].

The topic of the sociality of the state was chosen by V. M. Kartashov [12] as the background, the context and the discourse for the issues of legitimacy in the conditions of building the welfare state in Russia, which were studied by the author in detail. The author interprets the problem of the law reinforcement not only as a legal problem but also as a universal social one in the development of Bent's concept. Nevertheless, this dissertation is of interest exactly for the welfare state topic [32].

A. L. Pashukov, when defining the social essence of the state, supports the theory of Blau and Abramovitz [33], and formulates a concept that "at all the phases of political genesis, the structures having the public power" strive (or should strive) for "establishing a definite order that would allow for the realization of the universal social, corpora- tive and personal interests of the society's members, and also allow for the protection of those interests from unlawful encroachments". The above referenced author gives accent to the universal social essence of the state and the class essence of the state grouping both depending on "which social group's interests serve as a priority for the holders of the public political power". As A. L. Pashukov writes "in the first case, the interests of all the society are the priority for the state authorities. With this, the prevailing character of the universal social interests complements the acknowledgement and respect for the corporative interests of the social minorities, and the subjective interests of the separate representatives of the community. In its turn, the class nature of the state suggests the supremacy of the interests of those holding the power above the interests of the dependent; with this the interests of the social groups exercising public authority are furthered at the expense of restricting ad limiting the corporative and personal interests of the ordinary members of the society" [20].

The basis of the scientific concept of N. Yu. Vorobyova [8] is represented by the following theses (relevant for the present research): "The formation of the welfare rule-of-law state is a new phase in the development of the statehood which is characterized by setting the principle of the solidarity liability of the state and the civil society". The welfare state "is no longer the only subject that develops basic provisions and implements social policy". The mentioned policy should be implemented by the state bodies and other bodies (including by different institutions of the civil society) which should be delegated with a part of the social functions. "Conditioned by the essence of the welfare rule-of-law state, the right of the person to demand the satisfaction of his needs from the state, is limited with a level of satisfaction necessary for surviving and reproduction... Ensuring the necessary (sufficient) living standard depends on the social policy of the specific state and is conditioned not so much by the wealth status as by the following: first of all, by the factors that define the priority of the social values in the official ideology of the state, secondly - by the development level of the democratic political institutions and the civil society institutions, thirdly - by historical and social-cultural conditions, the specific 
type of the of the socio-political order", thus the progressive concept by Bose is developed [34].

In accordance with E. N. Naumova's [17] concept, the notion of the welfare state should be interpreted on the basis of presuming "the closest connection between the categories of the welfare state, social function and social policy" (the author insisted that the social function and the social policy are the principal means of the welfare state idea realization) with the account for the historical approach of Briggs [35]. With this, as the author wrote, "the national projects (health care, housing, education) are the "core" of the content of the mentioned categories at the modern phase of the Russian statehood development". As E. N. Naumova puts it, "the welfare state is a significant political legal characteristic of the modern Russian State", at the same time "the welfare state is simultaneously the purpose and actions for realizing this purpose, the parameters of the state activity in general and the social focus of all its functions".

I. V. Leonov views the welfare state as an "ideal" and "naturally determined phase of the state forms' evolutionary development", as "the highest achievement of the civilization in the sphere of the state construction and bringing the universal human values to life, the most practical way of combining freedom and power for the purpose of providing the welfare of the individual and the prosperity of the society in general", as an "evidence-based reply to the imperfectness of the state in its classical liberal model of the "night-watchman", as well as a reply to the failed attempt to build a state in the form of the administrative bureaucratic socialism". The author defines the welfare state as "the rule-of-law democratic state, with the supreme value being a human, and everyone's free development and creative potential realization", in accordance with the democratic approach of Brooks and Manza [36]. The juridical meaning of the mentioned is revealed through the postulation of the welfare state duty to legislatively acknowledge the social rights and to guarantee them in its daily law application and law enforcement activities. I. V. Leonov gives the following descriptive features of the welfare state:

1) the state positions the individual, his life, welfare and personal dignity as the supreme value;

2) the internal and external policies are connected with the imperative of protection of not only all- nation and group interests, but first of all - of the rights, freedoms and legitimate social economic interests of an individual and a citizen;

3) the social focus of the meaningful managerial decisions as part of the state management;

4) imperative demand from the state to implement active social policy providing for a social orientation of both the state and the private sectors of economy;

5) the state rests on the mutual social liability of the government, the society and the citizen [15].

V. A. Samoilenko thinks that the fundamental of the welfare rule-of-law state is the principle of the social justice of Castles [37] (as the main principle). This author sees the welfare state as "the only effective tool of smoothing the social contradictions and conflicts, the tool for providing equal opportunities to citizens for the realization of their personal desires, needs and interests" [24].

As defined in the concept of V. A. Uvachev, the modern welfare rule-of-law state can be described through the following features:

"1) preponderance of the "common activities" on protecting the interests of the society as a whole over the functions of protecting the private and interests, and consequently,

2) a definite tendency for the reinforcement of the public law role as compared to the private one;

3) systematic re-distribution of the national income for the benefit of the economically disadvantaged;

4) a notable restriction of the rights and freedoms of the owners for general welfare;

5) constant reinforcement of the moral aspect in the state's activities as compared to the legal one" [28].

V. A. Uvachev views the correlation of the state's sociality principle and the principle of the rule-of-law state, using the approach of Cousins [38] and coming to a conclusion that "the tendency of reinforcement of the social principle as compared to the legal one does not mean the abolishment of the legal principle, at least in the near-term historical perspective... Both the components are constantly present in the life of the... state". In the opinion of the author, "the principal specifics of the legal nature of the researched state is the availability of the social law in its legal system, with the social rights as the key element and the leading 
component of the system. The social right includes the social economic and cultural rights of a human. It has generalized subject and methods, general principles and methods of regulation, as well as its own criteria for systematization and codification of the legal acts. It regulates the relations in the social sphere and acts as a common branch of legislation defining it as the welfare legislation".

Using the approach of Deaton, T. V. Bychek researches the welfare state theme through the concept of the political legal regime of the welfare state and the social security concept $[7 ; 39]$.

E. G. Nechaeva interprets the welfare state as the "state where the principles of social justice and solidarity are legislatively established and are successively being implemented in all the spheres of the public life". The author reveals the essence of such a state through its connection with rule-of-law democratic state and defines its content by means of describing it with a row of "stable characteristics" presented by other authors. In her opinion, the stable characteristics mostly include those covering the social rights of the citizens or the mechanisms of the social policy, thus the author goes beyond the rows proposed by Deaton [18; 40].

The basis of E. V. Baklanova's understanding and interpreting of the welfare state of the concept of decent life of an individual and the society. The author considers the provision of such a life to be one of the purposes of the welfare state. According to the author, the right for a decent life (described in detail in her dissertation) is a specific right [6] occupying a special place in the human rights system; with this, the "criteria of a decent life of the individual and the decent life of the society do not coincide", that contradicting Deaton's point of view [41]. In the opinion of E. V. Baklanova, the praxeological approach in researching the specifics of the welfare state must be amended with a value-based approach, because only this approach allows to answer the question about what in particular underlies setting the social tasks by such a state, and what its activity content are defined by.

I. N. Nikovaenko, like a number of other authors, puts the human decent right notion and the corresponding human right into the basis of the social character of the state. This author reveals the essence of the "welfare rule-of-law state" de- fined by him, through the postulation that "such a state, unlike the "usual" welfare state and unlike its own liberal model, expresses historical compromise of the small class of monopolistic transnational bourgeoisie with the rest of the population, first of all - with the middle class. For preserving this compromise, it suppresses any attempt of the independent rising of any social forces that have the risk of upsetting the social balance", with this it goes beyond the limits of the concept proposed by De Frei [19; 42].

O. S. Kurchenko contributes to the scientific understanding and interpretation of the state with his concept of interpreting the "legal standing of the state in the social provision law" that is described by him as "the ability and real opportunity to be the bearer of the duties to provide for different types of social services" [14]. The author develops the model proposed by Einhorn [43]. As the author sees it, "the ability to be the bearer of the mentioned duties creates a "core" of the state legal standing with regard to the social provision. The opportunities of obtaining and realizing other rights and duties by the state concerning the social services (for example, in the sphere of the social partnership, in the sphere of the international regulation of relations associated with the social services) have a derivative character... The state legal standing in social provision is realized in social duties which are the material legal relations (based on law or other normative legal act) between the state and the citizens, where the citizens have a right to get specific types of social benefits if prescribed by law, and the state is to provide them acting through the authorized bodies and establishments".

I. A. Fedotov [29] chose the theme of the state as a background, context and discourse for his thoroughly researched topic of economical rights of the person and of the citizen, evaluation of their role and meaning in the complex of the human rights and freedoms described by Elsenhans [44] among others. The dissertation is also focused on discovering the criteria and the conditions for the most effective realization of the mentioned rights in the welfare state. Nevertheless, this dissertation is interesting for the welfare state topic.

E. G. Belikov [6] views the welfare state through the prism of the finance law. 
This is why, from his point of view, the observation of the social principle of Naldini [45] applied in the process of the property and personal income taxation, imposing and collecting the mandatory insurance payments to the state nonbudgetary social funds, distribution of the budgetary funds between the regions and the sectors of the national economy, in the process of public management and etc., is still relevant. With this, the introduction of the some benefits and social incentives in the budgetary and tax legislation does not relieve from the necessity of a complex and successful approach to the problems of the socially focused financial-legal regulation - in general, and fixation and introduction of incentives and other juridical means of financial law in particular.

\section{Semantic Kernel of the "Welfare State" Notion and the "Sociality of the State" Notion}

The analysis of the scientific works by the above authors allows us to single out the following approaches in interpreting the content quintessence of the welfare state notion:

- as a special public authority arrangement of the society in the concepts of L. A. Rezvanova [21] and others;

- as a special political-legal organization in concepts of N. A. Baieva [4] and others;

- as the essential characteristic of the state in concepts of U. A. Starshova [26] and others;

- as the essential characteristic of the modern state in concepts of E. N. Naumova [17];

- as both the purpose and the content of the state's activities in the concepts of E. N. Naumova [17];

- as an idea, as one of the fundamentals of the constitutional order and as the activities of the state institutions in the concepts of U. A. Starshova [26] and others;

- as a specific model of the government system arrangement in the concepts of A. E. Evstratova [10] and other;

- as a set of imperative requirements imposed on the state in the concepts of A. V. Sigarev [25], I. V. Leonov [15];

- as an effective means of smoothing the social disputes and conflicts, of providing equal opportunities to citizens for meeting their needs and interests in the concepts of V. A. Samoilenko [24];

- as an independent type or a special form of the rule-of-law state in the concepts of N. A. El- baeva [11], T. V. Yahontova [31], I. N. Nikolaenko [19], V. A. Uvachev [28] and others;

- as an element of the state form in concept of A. A. Aduhov [1];

- as a basis of the socially focused development of the financial legal regulation in the concept of E. G. Belikov [6].

\section{Proposals on the Development and Introduction of the Russian Federation Social Code}

The proposals on developing and adopting the Russian Federation Social Code are met in the dissertations of N. A. Baieva [4], U. A. Starshova [26].

N. A. Baieva proposes to expand this act with the "existing social legislation that fixes the social rights and their guarantees, and to close the gaps of the legislation in force. And in particular, to introduce the principle of the mandatory participation of the employable population in creating material and spiritual benefits; to establish organizational- managerial fundamentals, sources of financing used for providing the citizens with the social services, the system of citizens' material support and social servicing, the legal mechanism of the infringed right restoration" [4].

U. A. Starshova proposes to amend this act with "all the types of the social benefits and social provision, different types of help to families, children, the young, the disabled, the incapacitated, military men, employees of internal security bodies, internal military forces and other law enforcement institutions and members of their families" [26].

\section{Conclusions}

The analysis of the scientific works of the mentioned authors allows for a conclusion that the notion of "the social character of the state" is seldom found in the scientific works, let alone its interpretations. One can bring the example of A. E. Evstratov's approach [10] to the interpretation of the quintessence content of the social character of the state as of a special ideal.

This conclusion is also conditioned by the introduction of the concept official interpretation into the Russian Federation Constitution ${ }^{1}$. And in particular, Part 1 of Article 7 of the Russian Federation Constitution declares the state's social character

\footnotetext{
${ }^{1}$ Constitution of the Russian Federation: adopted through national voting on December 12, 1993 (with amendments introduced with RF Laws about Amendments to Constitution dd July 21, 2014 No. 11-FKZ). Collection of Laws of the Russian Federation. 2014. No. 31, Art. 4398.
} 
to be one of the fundamentals of the Russian Federation constitutional order, partially explaining this notion through presuming the state's policy focus on "creating conditions for a decent life and free development of individual". This constitutional legal provision corresponds to the provisions of the Preamble of the Russian Federation Constitution about "striving to ensure the wellbeing and prosperity of Russia" and about "responsibility for our Fatherland towards the present and future generations".

That is why the modern discussions of the Russian legal science about the proper content and focus of the constitutional ideology and constitutionalism in general, about the constitutional paradigm of Russia of the future, constantly result in the disputes about the quality and the fullness of any given constitutional norm wording [3].

\section{References}

1. Adukhov A. A. Forma gosudarstva $i$ ego sotsial'noe naznachenie: dis. ... kand. yurid. nauk [Form of the State and its Social Purpose: Cand. jurid. sci. diss.]. St. Petersburg, 2003. 174 p. (In Russ.).

2. Andreeva E. M. Sotsial'naya funktsiya demokraticheskogo gosudarstva: Konstitutsionnopravovoy aspekt: dis. ... kand. yurid. nauk [Social Function of the Democratic State: Constitutional and Legal Aspect: Cand. jurid. sci. diss.]. Moscow, 1998. 176 p. (In Russ.).

3. Aristov E. V. Sotsial'noe gosudarstvo v konstitutsionnom prave: $k$ voprosu o diskussii otnositel'no ponyatiya [Social State in the Constitutional Law: on the Discussion of the Notion]. Vestnik Permskogo Universiteta. Yuridicheskie nauki - Perm University Herald. Juridical Sciences. 2015. Issue 3(29). Pp. 8-14. (In Russ.).

4. Baieva N. A. Yuridicheskie garantii rossiyskogo sotsial'nogo gosudarstva: dis. ... kand. yurid. nauk [Legal Guarantees of the Russian Social State: Cand. jurid. sci. diss.]. Stavropol, 2005. 196 p. (In Russ.).

5. Baklanova E. V. Sushchnost' i kriterii dostoynoy zhizni cheloveka $i$ obshchestva kak tseli sotsial'nogo gosudarstva: dis. ... kand. yurid. nauk [The Essence and Criteria of a Decent Life of a Person and Society as a Goal of the Social State: Cand. jurid. sci. diss.]. Moscow, 2007. 174 p. (In Russ.).

6. Belikov E. G. Problemy finansovo-pravovogo obespecheniya razvitiya Rossiyskoy Federatsii kak sotsial'nogo gosudarstva: avtoref. dis. ... $d$-ra yurid. nauk [Problems of Financial and Legal Ensuring of the Development of the Russian Federation as a Social State: Synopsis of Dr. jurid. sci. diss.]. Saratov, 2016. 47 p. (In Russ.).

7. Bychek T. V. Politiko-pravovoy rezhim sotsial'nogo gosudarstva: voprosy teorii i praktiki v Rossiyskoy Federatsii: dis. ... kand. yurid. nauk [Political-Legal Regime of the Social State: Theory and Practice in the Russian Federation: Cand. jurid. sci. diss.]. Krasnodar, 2007. 246 p. (In Russ.).

8. Vorob'eva N. Yu. Gosudarstvo kak sub"ekt sotsial'noy politiki: Istoriko- i teoretiko-pravovoy aspekty: dis. ... kand. yurid. nauk [State as a Subject of Social Policy: Historical and Theoretical-Legal Aspects: Cand. jurid. sci. diss.]. St. Petersburg, 2005. 260 p. (In Russ.).

9. Gurlev A. V. Pravo cheloveka na dostoynuyu zhizn' kak osnovnaya tsennost' sotsial'nogo gosudarstva: dis. ... kand. yurid. nauk [The Human Right to a Decent Life as the Main Value of the Social State: Cand. jurid. sci. diss.]. St. Petersburg, 2001. 174 p. (In Russ.).

10. Evstratov A. E. Genezis idei sotsial'nogo gosudarstva: Istoriko-teoreticheskie problemy: dis. ... kand. yurid. nauk [Genesis of the Idea of the Social State: Historical and Theoretical Problems: Cand. jurid. sci. diss.]. Omsk, 2005. 234 p. (In Russ.).

11. Elbaeva N.A. Sotsial'naya zashchita kak institut sotsial'nogo gosudarstva: sushchnostnye i konstitutsionno-pravovye aspekty (na primere Respubliki Altay): dis. ... kand. yurid. nauk [Social Protection as an Institution of the Social State: Essential and Constitutional-Legal Aspects (a Case Study of the Republic of Altai): Cand. jurid. sci. diss.]. Moscow, 2003. 177 p. (In Russ.).

12. Kartashov V. M. Realizatsiya zakonnosti v usloviyakh postroeniya $v$ Rossii sotsial'nogo gosudarstva: dis. ... kand. yurid. nauk [Realization of Legality in the Conditions of Building a Social State in Russia: Cand. jurid. sci. diss.]. Rostov-on-Don, 2005. 134 p. (In Russ.).

13. Korobov S. E. Sotsial'naya funktsiya gosudarstva: dis. ... kand. yurid. nauk [Social Function of the State: Cand. jurid. sci. diss.]. Moscow, 2000. 181 p. (In Russ.).

14. Kurchenko O.S. Gosudarstvo kak sub"ekt prava sotsial'nogo obespecheniya: dis. ... kand. yurid. nauk [The State as a Subject of the Right to Social Security: Cand. jurid. sci. diss.]. Omsk, 2008. 205 p. (In Russ.).

15. Leonov I. V. Sotsial'noe gosudarstvo kak predmet teoretiko-pravovogo issledovaniya: dis. ... kand. yurid. nauk [Social State as a Subject of Theoretical and Legal Research: Cand. jurid. sci. diss.]. Moscow, 2006. 188 p. (In Russ.). 
16. Makedonskaya Zh. Kh. Pravovaya priroda Rossiyskoy Federatsii kak sotsial'nogo gosudarstva: dis. ... kand. yurid. nauk [The Legal Nature of the Russian Federation as a Social State: Cand. jurid. sci. diss.]. Moscow, 1997. 193 p. (In Russ.).

17. Naumova E.N. Sotsial'noe gosudarstvo $v$ Rossii: problemy teorii i praktiki: dis. ... kand. yurid. nauk [Social State in Russia: Problems of Theory and Practice: Cand. jurid. sci. diss.]. Vladimir, 2006. 172 p. (In Russ.).

18. Nechaeva E. G. Sotsial'noe gosudarstvo: pravovoe ponimanie i praktika: dis. ... kand. yurid. nauk [Social State: Legal Understanding and Practice: Cand. jurid. sci. diss.]. Moscow, 2007. 101 p. (In Russ.).

19. Nikolaenko I. N. Sotsial'no-pravovoe gosudarstvo $i$ pravo cheloveka na dostoynoe sushchestvovanie: dis. ... kand. yurid. nauk [Socio-Legal State and the Human Right to a Dignified Existence: Cand. jurid. sci. diss.]. Moscow, 2008. 194 p. (In Russ.).

20. Pashukov A. L. Sotsial'naya sushchnost', sotsial'naya funktsiya, sotsial'naya politika gosudarstva: Teoreticheskiy $i$ sravnitel'nopravovoy aspekty: dis. ... kand. yurid. nauk [Social Essence, Social Function, Social Policy of the State: Theoretical and Comparative Law Aspects: Cand. jurid. sci. diss.]. Moscow, 2005. 232 p. (In Russ.).

21. Rezvanova L. A. Sushchnost' sotsial'nogo gosudarstva i ee proyavlenie $v$ sfere obrazovaniya: dis. ... kand. yurid. nauk [The Essence of the Social State and Its Manifestation in the Sphere of Education: Cand. jurid. sci. diss.]. Rostov-onDon, 2004. 209 p. (In Russ.).

22. Rodionova O.V. Sotsial'noe gosudarstvo: Teoretiko-pravovoy aspekt: dis. ... kand. yurid. nauk [Social State: Theoretical and Legal Aspect: Cand. jurid. sci. diss.]. St. Petersburg, 2002. 197 p. (In Russ.).

23. Rodionova O.V. Sotsial'naya funktsiya sovremennogo gosudarstva: dis. ... kand. yurid. nauk [Social Function of the Modern State: Cand. jurid. sci. diss.]. Moscow, 2007. 353 p. (In Russ.).

24. Samoylenko V. A. Sotsial'naya funktsiya sovremennogo rossiyskogo gosudarstva: dis. ... kand. yurid. nauk [Social Function of the Modern Russian State: Cand. jurid. sci. diss.]. Kolomna, 2006. 220 p. (In Russ.).

25. Sigarev A. V. Konstitutsionnye osnovy sotsial'nogo gosudarstva v Rossiyskoy Federatsii: dis. ... kand. yurid. nauk [Constitutional Bases of the Social State in the Russian Federation: Cand. jurid. sci. diss.]. Novosibirsk, 2004. 192 p. (In Russ.).
26. Starshova U. A. Konstitutsionnye osnovy sotsial 'nogo gosudarstva $v$ Rossiyskoy Federatsii: dis. ... kand. yurid. nauk [Constitutional Bases of the Social State in the Russian Federation: Cand. jurid. sci. diss.]. Saratov, 2004. 219 p. (In Russ.).

27. Tkacheva G. V. Problemy obnovleniya sotsial'noy funktsii sovremennogo Rossiyskogo gosudarstva: dis. ... kand. yurid. nauk [Problems of Updating the Social Function of the Modern Russian State: Cand. jurid. sci. diss.]. Stavropol, 2004. 194 p. (In Russ.).

28. Uvachev V. A. Sotsial'no-pravovoe gosudarstvo i grazhdanskoe obshchestvo postindustrial'noy epokhi: pravovye osnovy funktsionirovaniya $i$ vzaimodeystviya (na primere stran Zapadnoy Evropy $i$ SShA): dis. ... kand. yurid. nauk [Socio-Legal State and Civil Society of the Post-Industrial Era: the Legal Foundations of Functioning and Interaction (a Case Study of Countries of Western Europe and the USA): Cand. jurid. sci. diss.]. Moscow, 2006. 191 p. (In Russ.).

29. Fedotov I. A. Ekonomicheskie prava cheloveka $i$ grazhdanina $v$ sotsial'nom gosudarstve: sovremennyy opyt Rossii: dis. ... kand. yurid. nauk [Economic Rights of the Man and Citizen in a Social State: the Contemporary Experience of Russia: Cand. jurid. sci. diss.]. Moscow, 2009. 205 p. (In Russ.).

30. Cherepennikov D. G. Stanovlenie i funktsionirovanie sotsial'nogo gosudarstva $v$ Rossii: Konstitutsionno-pravovye osnovy: dis. ... kand. yurid. nauk [Formation and Functioning of the Social State in Russia: Constitutional and Legal Bases: Cand. jurid. sci. diss.]. Moscow, 2001. 187 p. (In Russ.).

31. Yakhontova T. V. Institutsionalizatsiya sotsial'nogo pravovogo gosudarstva $v$ postsovetskoy Rossii: dis. ... kand. yurid. nauk [Institutionalization of the Social Legal State in PostSoviet Russia: Cand. jurid. sci. diss.]. Rostovon-Don, 2005. 177 p. (In Russ.).

32. Bent $G$. The A to $Z$ of the Welfare State. Lanham: The Scarecrow Press, 2009. 277 p. (In Eng.).

33. Blau J., Abramovitz M. The Dynamics of Social Welfare Policy. Oxford: Oxford University Press, 2003.518 p. (In Eng.).

34. Bose P. Welfare States in Perspective. Welfare States and the Future; ed. by B. Vivekanandan, N. Kurian. New York: Palgrave Macmillan, 2005. 409 p. (In Eng.).

35. Briggs A. The Welfare State in Historical Perspective. European Journal of Sociology. 1961. Issue 2. Pp. 16-29. (In Eng.).

36. Brooks C., Manza J. Why Welfare States Persist: The Importance of Public Opinion in De- 
mocracies. Chicago: The University of Chicago Press, 2007. Vol. XII. 195 p. (In Eng.).

37. Castles F. Comparative Public Policy. Northampton, MA: Edward Elgar Publishing Inc., 1998. 162 p. (In Eng.).

38. Cousins M. European Welfare States: Comparative Perspectives. London: SAGE Publications, 2005. 264 p. (In Eng.).

39. Deaton A., Muellbauer J. Economics and Consumer Behavior. Cambridge: Cambridge University Press, 1980. Vol. XIV. 450 p. (In Eng.).

40. Deaton A. The Analysis of Household Surveys: A Microeconometric Approach to Development Policy. Baltimore: The Johns Hopkins University Press, 1997. 479 p. (In Eng.).

41. Deaton A. Understanding Consumption. Oxford: Clarendon Press, 1992. Vol. XII. 242 p. (In Eng.).

42. De Frei J. Welfare State Classification: The Development of Central Eastern European Welfare States. Master thesis "International Public Policy and Management". Rotterdam, 2009. 51 p. (In Eng.).

43. Einhorn E. S., Logue J. Modern Welfare States: Scandinavian Politics and Policy in the Global Age. Second Edition. Westport: Praeger Publishers, 2003. Vol. XVIII. 403 p. (In Eng.).

44. Elsenhans H. A World Economy Based on the Welfare State Principle. Welfare States and the Future; ed. by B. Vivekanandan, N. Kurian. New York: Palgrave Macmillan, 2005. 409 p. (In Eng.).

45. Naldini M. The Family in the Mediterranean Welfare States. London: Frank Cass, 2005. 136 p. (In Eng.).

\section{References in Russian}

1. Адухов A. A. Форма государства и его социальное назначение: дис. ... канд. юрид. наук. СПб., 2003. 174 c.

2. Андреева Е. М. Социальная функция демократического государства: Конституционноправовой аспект: дис. ... канд. юрид. наук. M., 1998. $176 \mathrm{c}$.

3. Аристов Е. В. Социальное государство в конституционном праве: к вопросу о дискуссии относительно понятия // Вестник Пермского университета. Юридические науки. 2015. Вып. 3(29). С. 8-14.

4. Бачева Н. А. Юридические гарантии российского социального государства: дис. ... канд. юрид. наук. Ставрополь, 2005. 196 с.

5. Бакланова E. В. Сущность и критерии достойной жизни человека и общества как цели социального государства: дис. ... канд. юрид. наук. М., 2007. 174 с.
6. Беликов Е. Г. Проблемы финансово-правового обеспечения развития Российской Федерации как социального государства: автореф. дис. ... д-ра юрид. наук. Саратов, $2016.47 \mathrm{c}$.

7. Бычек Т. В. Политико-правовой режим социального государства: вопросы теории и практики в Российской Федерации: дис. ... канд. юрид. наук. Краснодар, 2007. 246 с.

8. Воробьева Н. Ю. Государство как субъект социальной политики: Историко- и теоретико-правовой аспекты: дис. ... канд. юрид. наук. СПб., 2005. 260 с.

9. Гурлев А. В. Право человека на достойную жизнь как основная ценность социального государства: дис. ... канд. юрид. наук. СПб., $2001.174 \mathrm{c}$.

10. Евстратов А. Э. Генезис идеи социального государства: Историко-теоретические проблемы: дис. ... канд. юрид. наук. Омск, 2005. $234 \mathrm{c}$.

11. Елбаева Н. А. Социальная защита как институт социального государства: сущностные и конституционно-правовые аспекты (на примере Республики Алтай): дис. ... канд. юрид. наук. М., 2003. 177 с.

12. Карташов В. М. Реализация законности в условиях построения в России социального государства: дис. ... канд. юрид. наук. Ростов н/Д., 2005. 134 с.

13. Коробов C.E. Социальная функция государства: дис. ... канд. юрид. наук. М., 2000. $181 \mathrm{c}$.

14. Курченко О.С. Государство как субъект права социального обеспечения: дис. ... канд. юрид. наук. Омск, 2008. 205 с.

15. Леонов И. В. Социальное государство как предмет теоретико-правового исследования: дис. ... канд. юрид. наук. М., 2006. 188 с.

16. Македонская Ж. Х. Правовая природа Российской Федерации как социального государства: дис. ... канд. юрид. наук. М., 1997. $193 \mathrm{c}$.

17. Наумова Е. Н. Социальное государство в России: проблемы теории и практики: дис. ... канд. юрид. наук. Владимир, 2006. 172 с.

18. Нечаева Е. Г. Социальное государство: правовое понимание и практика: дис. ... канд. юрид. наук. М., 2007. 101 с.

19. Николаенко И. Н. Социально-правовое государство и право человека на достойное существование: дис. ... канд. юрид. наук. М., 2008. $194 \mathrm{c}$.

20. Пашуков А. Л. Социальная сущность, социальная функция, социальная политика государства: Теоретический и сравнительно- 
правовой аспекты: дис. ... канд. юрид. наук. M., 2005. $232 \mathrm{c}$.

21. Резванова Л. А. Сущность социального государства и ее проявление в сфере образования: дис. ... канд. юрид. наук. Ростов н/Д., 2004. $209 \mathrm{c}$.

22. Родионова О. В. Социальное государство: Теоретико-правовой аспект: дис. ... канд. юрид. наук. СПб., 2002. 197 с.

23. Родионова О. В. Социальная функция современного государства: дис. ... канд. юрид. наук. М., 2007. 353 с.

24. Самойленко $\quad$ B. A. Социальная функция современного российского государства: дис. ... канд. юрид. наук. Коломна, 2006. $220 \mathrm{c}$.

25. Сигарев A. В. Конституционные основы социального государства в Российской Федерации: дис. ... канд. юрид. наук. Новосибирск, 2004. $192 \mathrm{c.}$

26. Старшова У. А. Конституционные основы социального государства в Российской Федерации: дис. ... канд. юрид. наук. Саратов, 2004. $219 \mathrm{c}$.

27. Ткачева Г. В. Проблемы обновления социальной функции современного Российского государства: дис. ... канд. юрид. наук. Ставрополь, 2004. $194 \mathrm{c.}$

28. Увачев B. A. Социально-правовое государство и гражданское общество постиндустриальной эпохи: правовые основы функционирования и взаимодействия (на примере стран Западной Европы и США): дис. ... канд. юрид. наук. М., 2006. 191 с.

29. Федотов И. А. Экономические права человека и гражданина в социальном государстве: современный опыт России: дис. ... канд. юрид. наук. М., 2009. 205 с.

30. Черепенников Д. Г. Становление и функционирование социального государства в России: Конституционно-правовые основы: дис. ... канд. юрид. наук. М., 2001. 187 с.

31. Яхонтова Т. В. Институционализация социального правового государства в постсоветской России: дис. ... канд. юрид. наук. Ростов н/Д., 2005. 177 с.
32. Bent $G$. The A to $\mathrm{Z}$ of the Welfare State. Lanham: The Scarecrow Press, 2009. 277 p.

33. Blau J., Abramovitz M. The Dynamics of Social Welfare Policy. Oxford: Oxford University Press, 2003. 518 p.

34. Bose P. Welfare States in Perspective // Welfare States and the Future / ed. by B. Vivekanandan, N. Kurian. New York: Palgrave Macmillan, 2005. 409 p.

35. Briggs A. The Welfare State in Historical Perspective // European Journal of Sociology. 1961. Issue 2. Pp. 16-29.

36. Brooks C., Manza J. Why Welfare States Persist: The Importance of Public Opinion in Democracies. Chicago: The University of Chicago Press, 2007. Vol. XII. 195 p.

37. Castles F. Comparative Public Policy. Northampton, MA: Edward Elgar Publishing, Inc., 1998. $162 \mathrm{p}$.

38. Cousins M. European Welfare States: Comparative Perspectives. London: SAGE Publications, 2005. $264 \mathrm{p}$.

39. Deaton A., Muellbauer J. Economics and Consumer Behavior. - Cambridge: Cambridge University Press, 1980. Vol. XIV. 450 p.

40. Deaton A. The Analysis of Household Surveys: A Microeconometric Approach to Development Policy. Baltimore: The Johns Hopkins University Press, 1997. 479 p.

41. Deaton A. Understanding Consumption. Oxford: Clarendon Press, 1992.Vol. XII. 242 p.

42. De Frei J. Welfare State Classification: The Development of Central Eastern European Welfare States / Master thesis International Public Policy and Management. Rotterdam, 2009. $51 \mathrm{p}$.

43. Einhorn E.S., Logue J. Modern Welfare States: Scandinavian Politics and Policy in the Global Age. Second Edition. Westport: Praeger Publishers, 2003. Vol. XVIII. 403 p.

44. Elsenhans H. A World Economy Based on the Welfare State Principle // Welfare States and the Future / Ed. by B. Vivekanandan, N. Kurian. New York: Palgrave Macmillan, 2005. 409 p.

45. Naldini $M$. The Family in the Mediterranean Welfare States. London: Frank Cass, 2005. $136 \mathrm{p}$. 